IdeAs

Idées d'Amériques

3 | 2012

L'alimentation dans les Amériques au prisme des sciences sociales

\title{
Comer juntos : confirmar a comunidade no quotidiano
}

Susana BLEIL

(2) OpenEdition

Journals

Édition électronique

URL : https://journals.openedition.org/ideas/536

DOI : $10.4000 /$ ideas.536

ISSN : 1950-5701

Éditeur

Institut des Amériques

Référence électronique

Susana BLEIL, "Comer juntos : confirmar a comunidade no quotidiano », IdeAs [En ligne], 3 | 2012, mis en ligne le 13 décembre 2012, consulté le 20 octobre 2022. URL : http://journals.openedition.org/ ideas/536 ; DOI : https://doi.org/10.4000/ideas.536

Ce document a été généré automatiquement le 20 octobre 2022

\section{(9) $(\mathbb{Q} \Theta \Theta$}

Creative Commons - Attribution - Pas d'Utilisation Commerciale - Pas de Modification 4.0 International - CC BY-NC-ND 4.0

https://creativecommons.org/licenses/by-nc-nd/4.0/ 


\title{
Comer juntos : confirmar a comunidade no quotidiano
}

\author{
Susana BLEIL
}

\section{NOTE DE L'AUTEUR}

Esta reflexão é fruto de nossa pesquisa de Doutorado em sociologia, com a Tese Engagements corps et âmes. Vies et luttes des Sans terre dans le Sud du Brésil na École des Hautes Études en Sciences Sociales (EHESS), Paris, 2009.

1 O que fazemos quando decidimos «comer juntos»? Esta pergunta nos veio quando realizávamos nossa pesquisa num assentamento ${ }^{1}$ do Movimento dos Trabalhadores Rurais Sem Terra (MST) no estado do Paraná, próximo à cidade de Paranacity. No assentamento, chamado Santa Maria, foi constituída uma Cooperativa, a COPAVI ${ }^{2}$ que organiza as refeições dos militantes num refeitório. Os militantes almoçam juntos, todos os dias da semana, neste lugar construído especialmente com o objetivo de possibilitar um momento de comunhão entre as famílias que vivem e trabalham juntas.

2 Saciar a fome pode ser a primeira resposta a esta pergunta. Ao menos, é a mais óbvia. Entretanto, é interessante problematizar esta questão utilizando a sociologia para «ver» o que pode acontecer «entre os indivíduos» quando estes têm o hábito, sistemático e quotidiano, de compartilhar seu almoço ${ }^{3}$. George Simmel oferece uma excelente reflexão sobre o papel das atividades realizadas em conjunto no que se refere ao fortalecimento do ser social ${ }^{4}$. Para este sociólogo, uma sociedade não existe de forma espontânea ou automática. Ao contrário, cada sociedade, para existir ao longo do tempo, necessita do trabalho sistemático de seus membros, através de ações recíprocas. Estas ações são sempre realizadas com determinados motivos ou interesses. Assim, um número dado de indivíduos pode constituir uma sociedade, mais ou menos coesa, cada vez que decide realizar ações conjuntas. Dito de outra forma, uma sociedade é construída a cada instante, (ou não) toda vez que seus membros decidem fazer o esforço de sair de seu conforto pessoal, do seu mundo bem conhecido, da sua facilidade 
de estar sozinho para entrarem em relação e aceitar o desconhecido que existe em cada situação coletiva.

3 Compartilhar uma refeição é, por excelência, uma das ações que faz com que um grupo torne-se mais «sociedade ». Ou seja, o hábito de deixar o calor e a familiaridade da "sua casa", ou "das suas preferências e gostos alimentares" pode resultar numa transformação profunda no tipo de relação que estes indivíduos poderão construir com seus pares.

4 Cada militante, se utilizamos o nosso exemplo do MST, torna-se mais unido ao grupo, mais « ligado » ao seu vizinho, do que poderia chegar a ser se não tivesse optado em «fazer » deste hábito de se alimentar, um hábito social.

5

Como isso pode ser verificado? Em nosso estudo verificamos que a idéia de ir ao refeitório para comer todos juntos era, inicialmente, algo muito distante da cultura e das preferências destas famílias de origem rural. o testemunho destes militantes mostra que ir ao refeitório era um verdadeiro « absurdo ", que muitos tinham vergonha de estar tão próximos, compartilhando a comida. Entretanto, como era uma necessidade maior para a COPAVI que as mulheres pudessem trabalhar ao lado dos homens, não tendo que parar para fazer o almoço em suas casas, todos resolveram se adaptar.

6 Esta ação se tornou um hábito e hoje muitos dizem que comer em suas casas, cada família isoladamente, seriam algo muito estranho e não poderiam mais se adaptar a isso.

7 Nossa pesquisa mostrou que durante o momento de « comer juntos » os militantes Sem Terra conversam, se escutam, se observam. Em outras palavras, os militantes podem, neste momento único, trocar sorrisos e caretas, sem a « obrigação de agir para produzir algo determinado ", o que geralmente é percebido como estando ligado à atividade de trabalho. Neste momento eles estão juntos com o único objetivo de «se dar prazer ». A fome, que deve ser satisfeita, não é o objetivo mais importante do encontro. A fome é, de certa forma, um objetivo secundário em relação a união que se constrói reciprocamente entre os convivas.

8 Durante nosso trabalho de campo na COPAVI nós pudemos comer com as famílias e ainda está bem viva em nossa memória esta cena (que não se alterou entre 2000 e 2003), composta de todas as famílias sentadas juntas, conversando num clima agradável e pacífico.

9 No final da refeição, cada militante saía do refeitório e ia fazer parte da fila formada na frente do tanque, para lavar seu prato. Este gesto era imitado até pelas crianças de sete e oito anos, mostrando como o exemplo de autonomia pode ser desenvolvido precocemente quando estamos num coletivo.

10 Nossa pesquisa tinha como objetivo verificar como se constroem as relações entre os militantes da COPAVI, ou seja, como é possível a cada militante se comprometer com o grupo e com a "luta dos Sem Terra ». Não era fácil para nós compreender como é possível a estes indivíduos aceitar não apenas viver neste assentamento mas também colaborar ativamente com a organização dos Sem Terra.

11 Nossa conclusão foi que existem muitas regras, ações e práticas coletivas neste assentamento que incitam os militantes a se sentirem parte de uma família, «a família COPAVI». Dentre estas ações, verificamos que o hábito de "comer juntos» 
desempenha um papel fundamental na união das famílias deste assentamento e, de certa forma, na construção da sociedade dos « Sem Terra » de todo país.

\section{NOTES}

1. «Assentamento" é o nome dado a todo estabelecimento rural regularizado pelo Governo Federal. Nesta propriedade vivem famílias que receberam o direito oficial de cultivar uma parcela de terra.

2. Cooperativa de Produção Agropecuária Vitória (COPAVI).

3. Este assunto foi abordado na nossa Tese de Mestrado « Mudança de hábitos a partir da industrialização agroalimentar ", Programa de Pós-graduação de Ciências Sociais em Desenvolvimento, Agricultura e Sociedade, (CPDA)/Universidade Federal Rural do Rio de Janeiro (UFRRJ), 1998. Para as principais conclusões deste estudo cf. o artigo «O padrão alimentar ocidental: considerações sobre a mudança de hábitos no Brasil ", Cadernos de Debate, n 6, 1998 : 1-25.

4. George Simmel, «Le problème de la sociologie » p. 39-79 in G. Simmel, Sociologies : Études sur les formes de la socialisation, Paris : PUF, 1999 (1908).

\section{AUTEUR}

\section{SUSANA BLEIL}

Susana Bleil est maître de conférences à l'Université du Havre en langue portugaise et civilisation brésilienne. Récemment, elle a publié l'ouvrage Vie et lutte des sans terre au sud du Brésil, Paris, Karthala, (préface de Luc Boltanski), 2012. Email: susanapointbleil7atorangepointfr. 